\title{
The use of dead stand trees by birds: a prospective study in a Brazilian hydroelectric dam
}

\author{
Andréia Cristina de Oliveira ${ }^{1}$, Elliott Centeno ${ }^{1}{ }^{\circledR}$, Jasmine de Resende Assis ${ }^{1}$, Phabliny Martins Silva Bom- \\ fim $^{1}$ \& César Cestari ${ }^{1}$ \\ ${ }^{1}$ Universidade Federal de Uberlândia, Programa de Pós-graduação em Ecologia e Recursos Naturais, Campus \\ Umuarama, Uberlândia, MG, Brasil. \\ *Corresponding author:dedeiacrist@yahoo.com.br
}

OLIVEIRA, A.C., CENTENO, E., ASSIS, J.R., BOMFIM, P.M., CESTARI, C. The use of dead stand trees by birds: a prospective study in a Brazilian hydroelectric dam. Biota Neotropica 20(3): e20190939. https://doi.org/10.1590/1676-0611-BN-2019-0939

\begin{abstract}
Hydropower constructions cause severe disturbances to biodiversity. Arboreal plants die after flooding; however, they expose their emerged branches (also called paliteiros) as a new habitat for animals and plants. Nothing is known about how paliteiros influence the presence of aquatic birds. This study verified which species of birds use the paliteiros, what are their behaviors and probably consequences to ecological processes. In November 2018, we sampled $5 \mathrm{~km}$ of paliteiros recording perched birds and their behaviors in the Três Marias dam, a 1040 $\mathrm{km}^{2}$ flooded area in southeastern Brazil. In total, 5.4\% of paliteiros were used by 14 bird species. The Neotropic Cormorant Nannopterum brasilianus (Gmelin, 1789) was the most frequent species. Birds mainly preened feathers; they also rested (with no apparent activity), defecated, hunted, fed, vocalized and drank water. Attention must be focused to some behaviors such as resting and defecation, which may influence long-term ecological processes (e.g., incorporating additional organic matter and changing aquatic community) in the dam.
\end{abstract}

Keywords: Behavior; Birds; Hydropower building; Human impact.

\section{O uso de paliteiros por aves: um estudo prospectivo em uma usina hidrelétrica no Brasil}

Resumo: Construções de hidrelétricas causam severos distúrbios à biodiversidade. Após a inundação de grandes áreas as plantas arbóreas morrem, apesar disso, elas deixam expostos seus galhos emersos (também chamados de paliteiros) criando um novo hábitat para animais e plantas. Nada se sabe sobre como os paliteiros influenciam a presença de aves aquáticas. Este estudo verificou quais espécies de aves utilizam os paliteiros, quais comportamentos elas exibem e suas prováveis consequências para processos ecológicos. Em novembro de 2018 foram amostrados $5 \mathrm{~km}$ de paliteiros, as aves empoleiradas nestas estruturas e seus comportamentos na represa de Três Marias, uma área inundada de $1040 \mathrm{~km}^{2}$ no sudeste do Brasil. Ao total, 5.4\% das árvores mortas foram utilizadas por 14 espécies de aves. O biguá Nannopterum brasilianus (Gmelin, 1789) foi a espécie mais frequente nos paliteiros. As aves frequentemente limparam as penas, descansaram (sem nenhuma atividade aparente), defecaram, caçaram, se alimentaram, vocalizaram e beberam água. Mais atenção deve ser focada em alguns comportamentos das aves tais como o descanso seguido de defecação que podem influenciar processos ecológicos a longo prazo (p. ex., a incorporação de matéria orgânica e mudança de comunidade aquática) na represa.

Palavras-chave: Aves; comportamento; construção de hidrelétricas; impacto humano. 


\section{Introduction}

Human impacts tied to the exponential increase of urbanization are considered major forces to the loss of biodiversity (McDonald et al. 2013). The construction of dams to generate electricity is a widespread example of impact that converts natural areas to artificial areas. It emerged by manipulation of natural water courses and creation of reservoirs which can cause serious disturbances to biodiversity (Stanford \& Ward 1992, Forsberg et al. 2017). Many terrestrial animals and plants are excluded from local community after flooding of large areas due to habitat loss (Báldi et al. 1998, Mallik \& Richardson 2009). Despite it, damming also results in the appearing of new habitats such as remaining dead and standing trees called "paliteiros". In many cases, some species of birds may profit in dams by the changes promoted by humans and individuals within population may adjust to disturbances of their environment (Reitan \& Thingstad 1999). Therefore, aquatic birds can use paliteiros as a perching substrate, however, nothing is known about their frequency of use and behaviors that they exhibit.

A similar and parallel example of remaining perching structure to birds are the scattered trees in human-modified terrestrial landscapes that are useful to species as resting and feeding places during movements between areas serving as stepping stones (Manning et al. 2006). Frugivorous birds can rest or feed in scattered trees or artificial perches and they can defecate and regurgitate seeds contributing to natural regeneration of degraded areas. Also, perches are used by birds to hunt other organisms like ants and rodents thus contributing to a balanced food chain (Herrera \& Garcia 2009, Guidetti et al. 2016, Vogel et al. 2018).

The Brazilian territory is privileged in watersheds and it is the second country that generates more hydropower in the world (behind China), with hydroelectricity totaling $68.1 \%$ of the country's electricity and more than 290 large dams (Oliveira 2018). Although the negative perspective on low biodiversity found after construction of hydroelectric dams (Batista et al. 2012), no knowledge exists of what concerns the influence of dead standing trees as perching structures for birds in flooded areas and its ecological importance. Here, we verified which species of birds use the paliteiros in the Três Marias dam located in southeastern Brazil. We also recorded what behaviors birds exhibit and if the quantity of dead branches in paliteiros may influence their momentary presence in the flooded area. With this study, we expect to raise initial information about the use of paliteiros by birds and their ecological consequences in dams.

\section{Methods}

\section{Study area}

The study was conducted at Pirapitinga Ecological Station (PES), which has an approximate area of $1,090 \mathrm{ha}$ and $20 \mathrm{~km}$ perimeter. It is located in the reservoir of Três Marias hydroelectric power in the municipality of Morada Nova de Minas, Minas Gerais State, southeast Brazil. The PES is located at the confluence of the Riachão stream with the São Francisco river (18 $20^{\circ}$ ' S - $18^{\circ} 23^{\prime} \mathrm{S}$ and $45^{\circ} 17^{\prime} \mathrm{W}-45^{\circ} 20^{\prime} \mathrm{W}$ ) (Azevedo et al. 1987)(Figure 1). It is surrounded by a high amount of paliteiros resulted from dead savanna or Cerrado trees caused by the flooding of 1962 . The paliteiros emerged 6-7 years ago due to the reduction of the water level of the dam. There are 36 species of aquatic birds in the PES area (Plano de Manejo Estação Ecológica de Pirapitinga 2013).

\section{Data collection}

Data collection was conducted by a team of five people in the morning from $07: 30 \mathrm{~h}$ to $12: 00 \mathrm{~h}$ on 26 November 2018 . Approximately

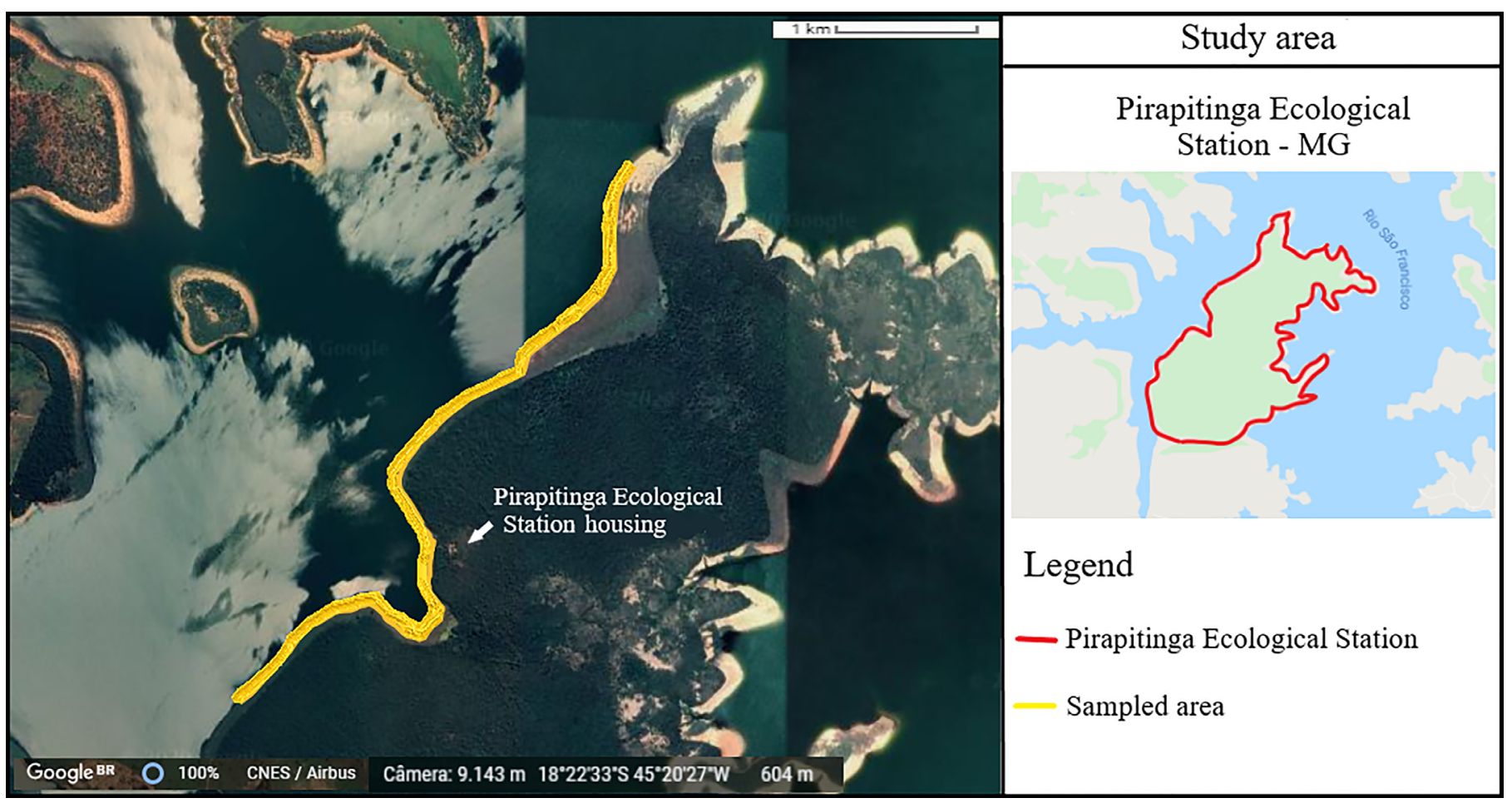

Figure 1. Location of the study area. Paliteiros were sampled in the border of Pirapitinga Ecololgical Station, southeastern Brazil. 
$5 \mathrm{~km}$ of paliteiros were sampled at the edge of the main channel from Três Marias dam, near the PES housing. We sampled the abundance of dead trees in paliteiros, the bird species richness and the frequency of use of paliteiros by birds as well as their behavior when perched in an emerged branch (or tip). Different portions of paliteiros were sampled simultaneously to avoid double counting of the same individual bird. We treated one paliteiro as a total of 100 tips of emerged branches (i.e., above water surface) which corresponds to $33 \pm 8.30$ dead trees (see results). Some of the branches were bifurcated and contained more than one tip. Other future studies may differently deal a paliteiro unit than us considering that there is no previous definition of how many trees or tips form a paliteiro unit. Perched birds were identified, counted and observed with the aid of binoculars. The focal animal technique was applied for 30 seconds per bird and bird behavior was identified and quantified. We classified bird behavior into nine categories: (1) resting, when perched birds apparently exhibited no active behavior; (2) preening, when birds cleaned feathers with beak or feet; (3) hunting, when birds flew or dove to chase a prey; (4) feeding; (5) drinking; (6) defecating; (7) communicating, when birds vocalized; (8) nesting, when birds had a nest or were building a nest; and (9) drying feathers with opened wings. The nomenclature of the species follows the Brazilian Ornithological Records Committee (Piacentini et al. 2015).

\section{Data analyses}

Jackknife 1 estimator was used to estimate the number of bird species in paliteiros. We also used a logistic regression to know if the number of dead trees (i.e., sampling units) in paliteiros influenced the presence/absence of birds. An emerged individual branch (i.e., with one tip) or an emerged and bifurcated branch (i.e., with two or more tips) is the closest way of what we found to represent a dead tree. This procedure was taken because we did not have access to the submerged and complete structure of branches and stems to accurately isolate individual trees in the dam.

The species accumulation curve with rarefaction method analysis was used to know the representativeness of bird species considering the number of paliteiros and number of birds sampled, respectively. The same procedure was adapted to know the representativeness of bird behavior types. In this case, we considered types of behavior instead specific species. Analyses were performed in R Statistical software v 3.5.1 (R Core Team 2019). "Vegan" was the complementary R package used in the analyses.

\section{Results}

We sampled 28 paliteiros in PES. Each paliteiro has $33 \pm 8.30$ dead trees (maximum and minimum number of trees were 65 and 20, respectively). Seventy-three birds of 14 species used $5.4 \%(\mathrm{~N}=48)$ of the total number of dead trees $(\mathrm{N}=888)$ in paliteiros. The Neotropic Cormorant Nannopterum brasilianus (Gmelin, 1789) was the most frequent species (Figure 2). The number of dead trees did not influence the presence of birds in paliteiros $(\mathrm{df}=26 ; \mathrm{z}=-0.54 ; p=0.59)$. Jackknife 1 estimated $20.75 \pm 2.55$ (SE) species of birds to the sampled area. Rarefaction method analysis estimated the need of four paliteiros (or 400 tips or nearly 12 dead trees) or 10 individuals of birds to record an additional species of bird.
Preening was the most frequent behavior used by birds followed by resting (Figure 3, Table 1). No nesting or wing-drying behaviors were recorded. Rarefaction method analysis estimated the need of eight paliteiros (or 800 tips or nearly 24 dead trees) or 16 individuals of birds to record a new type of behavior.

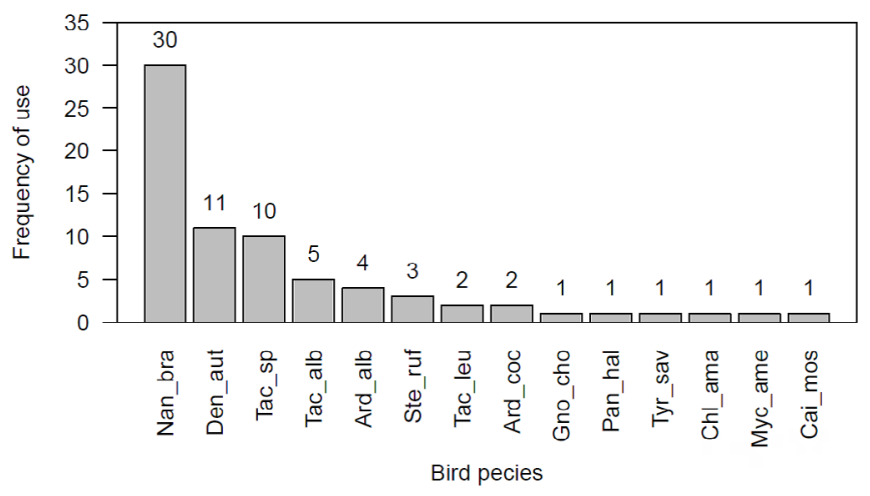

Figure 2. Bird species and their frequency of use of paliteiros in Três Marias dam, southeastern Brazil. Numbers above bars evidence the frequency of use of paliteiros by each bird species. Nan_bra: Nannopterum brasilianus; Den_aut: Dendrocygna autumnalis; Tac_sp: Tachycineta $\mathrm{sp}$.; Tac_alb: Tachycineta albiventer; Ard_alb: Ardea alba; Ste_ruf: Stelgidopteryx ruficollis; Tac_leu: Tachycineta leucorrhoa; Ard_coc: Ardea cocoi; Gno_cho: Gnorimopsar chopi; Pan_hal: Pandion haliaetus; Tyr_sav: Tyrannus savanna; Chl_ama: Chloroceryle amazona; Myc_ame: Mycteria americana; Cai_mos: Cairina moschata.

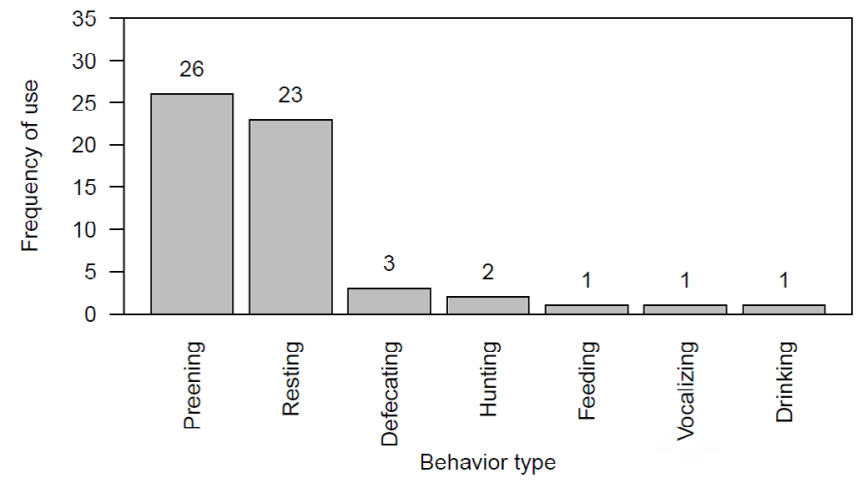

Figure 3. Types of bird behavior and their frequency of use in paliteiros from Três Marias dam, southeastern Brazil. Numbers above bars evidence the frequency of behavior.

\section{Discussion}

The present study was the first to evaluate the use of paliteiros by birds. Twelve out of 14 species were aquatic birds and they represented $33.3 \%$ of a total of 36 species of aquatic birds in the entire region (Plano de Manejo Estação Ecológica de Pirapitinga 2013). The Jackknife estimator pointed that no more than 21 species or $58 \%$ of total species may use paliteiros in the region. Also, birds showed a variety of behaviors when perched in paliteiros. Although the short-time nature of our results, we sampled a significant number of dead trees and this prospective study incorporated a sampling protocol that can be used in future researches regarding the use of paliteiros by birds. Furthermore, we argue that more attention also must be focused to some behaviors 
Oliveira AC. et al.

Table 1. Bird species and their behaviors when perched on paliteiros in Três Marias dam, southeastern Brazil. (P) preening, (R) resting, (D) defecating, (H) hunting, (F) feeding, $(\mathrm{V})$ vocalizing, and (Dr) drinking. Number in parenthesis indicates the frequency of behavior type.

\begin{tabular}{|c|c|c|c|}
\hline Taxa & Portuguese name & English name & Behavior \\
\hline \multicolumn{4}{|l|}{ Anseriformes Linnaeus, 1758} \\
\hline \multicolumn{4}{|l|}{ Anatidae Leach, 1820} \\
\hline Dendrocygna autumnalis (Linnaeus, 1758) & marreca-cabocla & Black-bellied Whistling-Duck & $\mathrm{R}(4), \mathrm{D}(1), \mathrm{P}(2), \mathrm{V}(1)$ \\
\hline Cairina moschata (Linnaeus, 1758) & pato-do-mato & Muscovy Duck & $\mathrm{P}(1)$ \\
\hline \multicolumn{4}{|l|}{ Ciconiformes Bonaparte, 1854} \\
\hline \multicolumn{4}{|l|}{ Ciconiidae Sundevall, 1836} \\
\hline \multicolumn{4}{|l|}{ Suliformes Sharpe, 1891} \\
\hline \multicolumn{4}{|l|}{ Phalacrocoracidae Reichenbach, 1849} \\
\hline Nannopterum brasilianus (Gmelin, 1789) & Biguá & Neotropic Cormorant & $\mathrm{R}(5), \mathrm{D}(2), \mathrm{P}(8), \operatorname{Dr}(1)$ \\
\hline \multicolumn{4}{|l|}{ Pelecaniformes Sharpe, 1891} \\
\hline \multicolumn{4}{|l|}{ Ardeidae Leach, 1820} \\
\hline \multicolumn{4}{|l|}{ Pandionidae Bonaparte, 1854} \\
\hline Pandion haliaetus (Linnaeus, 1758) & águia-pescadora & Osprey & $\mathrm{P}(1)$ \\
\hline \multicolumn{4}{|l|}{ Coraciiformes Forbes, 1844} \\
\hline \multicolumn{4}{|l|}{ Alcedinidae Rafinesque, 1815} \\
\hline Chloroceryle amazona (Latham,1790) & martim-pescador-verde & Amazon Kingfisher & $\mathrm{R}(1), \mathrm{H}(1), \mathrm{F}(1)$ \\
\hline \multicolumn{4}{|l|}{ Passeriformes Linnaeus, 1758} \\
\hline \multicolumn{4}{|l|}{ Tyranninae Vigors, 1825} \\
\hline Tyrannus savana Daudin, 1802 & Tesourinha & Fork-tailed Flycatcher & $\mathrm{P}(1)$ \\
\hline \multicolumn{4}{|l|}{ Hirundinidae Rafinesque, 1815} \\
\hline Stelgidopteryx ruficollis (Vieillot, 1817) & Andorinha-serradora & Southern Rough-winged & $\mathrm{R}(1), \mathrm{P}(2)$ \\
\hline
\end{tabular}

(e.g., defecation, and hunting) that may influence ecological processes in dams.

The water level of the Três Marias dam has been reduced and exposed the dead arboreal trees 6-7 years ago. Although the number of dead trees did not influence the presence of birds in paliteiros, a gradual process of colonization and use of paliteiros by aquatic bird species should be occurring in the area. During the colonization process, several adaptations (e.g., life history, general tolerance to disturbances, ability to disperse to other habitats) that are specific for species affect the possibilities for each bird to adjust (or not) its behavior in human-altered conditions. For instance, the Neotropic Cormorant (N. brasilianus), a top aquatic predator, was the most frequent species in our study and it may be considered as an example of generalist species with high incidence of colonization in anthropic environments (Orta 1994, Sick 1997). The cormorants showed a bunch of behaviors in the paliteiros and they opportunistically hunts a variety of prey using submerged and efficient dives in small and large natural and artificial lakes, as well as in rivers and marine ecosystems throughout the Brazilian territory
(Barquete et al. 2008). The presence of cormorants and other aquatic top predator birds (e.g., heron and kingfishers) may alter significantly their prey abundance (Steinmetz et al. 2003).

Some birds that defecated in paliteiros may have acted as fertilizer agents incorporating additional organic matter into water and/or acting as food provider to detritivorous species (e.g., fish and crustaceans). Therefore, birds may play an important role as nutrient vectors (mainly phosphorus and nitrogen) which interfere in the trophic chain of aquatic ecosystems (Manny et al. 1994). This is a similar mechanistic process that occurs when frugivorous birds defecate seeds from perches in degraded areas: they may feed other organisms (e.g. ants), increase the seed bank, and indirectly modify the local community of plants and animals (Christianini \& Oliveira 2009, Herrera \& Garcia 2009, Guidetti et al. 2016). Furthermore, some usual bird places such as dormitories and rookeries may be more protected from predators when they border aquatic ecosystems similarly to paliteiros; the high concentration of individuals (including their droppings) may change local macrophytes biomass and their associated organisms (Castelo-Branco 2008). More 
studies are necessary to investigate if paliteiros facilitate or attract higher concentration of other organisms such as plants, fish and invertebrates.

The use of paliteiros by birds is a recent and underexploited theme. Our study is far from a definitive conclusion, however, it is the first step to discover more information about the importance of this manaltered habitat to birds and how the presence of birds may positively or negatively influence ecological processes. We encourage more comparative studies to verify if older flooded areas with paliteiros may have higher bird biodiversity than recent ones and if birds may comprise more specific ecological functions in the local food chain.

\section{Acknowledgments}

We thank the Graduation Program in Ecology and Natural Resources of the Universidade Federal de Uberlândia and the staffs from Instituto Chico Mendes de Conservação da Biodiversidade (ICMBio) working at Pirapitinga Ecological Station. This study was financed in part by the Coordenação de Aperfeiçoamento de Pessoal de Nível Superior Brasil (CAPES) - Finance Code 001. CC receives a research grant from Capes (88882.314750/2019-01) and EC receives a research grant from CNPq (131159/2018-6).

"The authors declare that they have no conflict of interest related to the publication of this work."

\section{Author Contributions}

Substantial contribution to the conception and design of the work: C. Cestari.

Contribution to data acquisition: A.C. de Oliveira, E. Centeno, J.R. Assis, P.M.S. Bomfim, C. Cestari.

Contribution to data analysis and interpretation: C. Cestari.

Contribution to the writing of the paper: A.C. de Oliveira, E. Centeno, J.R. Assis, P.M.S. Bomfim, C. Cestari.

\section{References}

AZEVEDO, L.G. et al. 1987. Ensaio Metodológico de Identificação e Avaliação de Unidades Ambientais: a Estação Ecológica de Pirapitinga, MG. Ministério do Desenvolvimento Urbano e Meio Ambiente, SEMA, Belo Horizonte, Minas Gerais, Brasil.

BÁLDI, A., MOSKAT, C. \& ZÁGON, A. 1998. Faunal mapping of birds in a riparian area of River Danube after construction of a hydroelectric power station. Folia Zoologica-Praha 47: 173-180.

BARQUETE, V., BUGONI, L. \& VOOREN, C.M. 2008. Diet of Neotropic cormorant (Phalacrocorax brasilianus) in an estuarine environment. Marine Biology 153: 431-443.

BATISTA, B.M.F., SILVA, J.V., SÁNCHEZ, D.C.M., MARTINEZ, D.T. \& PASA, M.C. 2012. Revisão dos impactos ambientais gerados na fase de instalação das hidrelétricas: Uma análise da sub-bacia do Alto Juruena-MT. Biodiversidade 11: 69-85.

CASTELO-BRANCO, M.B. 2008. Comunidade de aves aquáticas e suas interações em sistemas límnicos do sudeste brasileiro. Tese de Doutorado, Universidade Federal de São Carlos, São Carlos, São Paulo.

CHRISTIANINI, A.V. \& OLIVEIRA, P. S. 2009. The relevance of ants as seed rescuers of a primarily bird-dispersed tree in the Neotropical cerrado savanna. Oecologia 160(4): 735-745.

FORSBERG, B.R., MELACK, J.M., DUNNE, T., BARTHEM, R.B., GOULDING, M., PAIVA, R.C., SORRIBAS, M.V., SILVA JR., U.L. \& WEISSER, S. 2017. The potential impact of new Andean dams on Amazon fluvial ecosystems. Plos One 12: e0182254.
GUIDETTI, B.Y., AMICO, G.C., DARDANELLI, S. \& RODRIGUEZ-CABAL, M.A. 2016. Artificial perches promotes vegetation restoration. Plant Ecology 217(7): 935-942.

HERRERA, J.M. \& GARCÍA, D. 2009. The role of remnant trees in seed dispersal through the matrix: Being alone is not always so sad. Biological Conservation 142: 149-158.

MALLIK, A.U. \& RICHARDSON, J.S. 2009. Riparian vegetation change in upstream and downstream reaches of three temperate rivers dammed for hydroelectric generation in British Columbia, Canada. Ecological Engineering 35: 810-819.

MANNY, B.A., JOHNSON, W.C. \& WETZEL, R.G. 1994. Nutrient additions by waterfowl to lakes and reservoirs: predicting their effects on productivity and water quality. Aquatic Birds in the Trophic Web of Lakes. Hydrobiologia 279/280: 121-132.

MANNING, A.D., FISCHER, J. \& LINDENMAYER, D.B. 2006. Scatterde trees are keystone structures - implications for conservation. Biological Conservation 132: 311-321.

MCDONALD, R.I., MARCOTULLIO, P.J. \& GUÈNERALP, B. 2013. Urbanization and global trends in biodiversity and ecosystem services. In Urbanization, biodiversity and ecosystem services: challenges and opportunities (T. Elmqvist, M. Fragkias, J. Goodness, B. Guèneralp, P.J. Marcotullio, R.I. McDonald, S. Parnell, M. Scheweneus, M. Sendstad, K.C. Seto \& C. Wilkinson eds.). Springer Netherlands, Springer, p. 31-52.

OLIVEIRA, N.C.C. 2018. The great acceleration and hydroelectric dam building in Brazil. Varia Historia 34(65): 315-346.

ORTA, J. 1994. Cormorants (Phalacrocoracidae). In Handbook of the Birds of the World Alive (J. del Hoyo, A. Elliott, J. Sargatal, D.A. Christie \& E. de Juana eds.). Lynx Edicions, Barcelona, Spain.

PIACENTINI, V.Q., ALEIXO, A., AGNE, C.E., MAURICIO, G.N., PACHECO, J.F., BRAVO, G.A., BRITO, G.R.R., NAKA, L.N., OLMOS, F., POSSO, S., SILVEIRA, L.F., BETINI, G.S., CARRANO, E., FRANZ, I., LEES, A.C., LIMA, L.M., PIOLI, D., SCHUNCK, F., AMARAL, F.R., BENCKE, G.A., COHN-HAFT, M., FIGUEIREDO, L.F.A., STRAUBE, F.C. and CESARI, E., 2015. Annotated checklist of the birds of Brazil by the Brazilian Ornithological Records Committee. Revista Brasileira de Ornitologia 23(2): 91-298.

PLANO DE MANEJO. ESTAÇÃO ECOLÓGICA DE PIRAPITINGA 2013. http://www.icmbio.gov.br/portal/images/stories/docs-planos-de-manejo/ esec_pirapitinga_pm.pdf (Last acess 07/12/2018).

R CORE TEAM 2019. R: A language and environment for statistical computing. $\mathrm{R}$ foundation for Statistical Computing: Vienna. http://www.R-project.org (Last access 24/10/2019).

REITAN, O. \& THINGSTAD, P.G. 1999. Responses of birds to damming - a review of the influence of lakes, dams and reservoirs on bird ecology. Ornis Norvegica 22: 3-7.

SICK, H. 1997. Ornitologia Brasileira. 2 ed. Nova Fronteira, Rio de Janeiro, Brasil.

STANFORD, J.A. \& WARD, J.V. 1992. Management of aquatic resources in large catchments: recognizing interactions between ecosystem connectivity and environmental disturbance. In Watershed Management. Balancing Sustainability and Environmental Change (R.J., Naiman, ed.). Springer Verlag, New York, p. 91-124.

STEINMETZ, J., KOHLER, S. L. \& SOLUK, D. A. 2003. Birds are overlooked top predators in aquatic food webs. Ecology 84(5): 1324-1328.

VOGEL, H.F., MCCARRON, V.E.A. \& ZOCCHE, J.J. 2018. Use of artificial perches by birds in ecological restoration areas of the Cerrado and Atlantic Forest biomes in Brazil. Neotropical Biology and Conservation 13(1): 24-36.

Received: 09/01/2020

Revised: 08/04/2020

Accepted: 06/05/2020

Published online: 01/07/2020 